\title{
The Rise of Private Regulation in the World Economy
}

N 28 August 2008, the world financial community awoke to stunning headline news: the Securities and Exchange Commission (SEC), the powerful U.S. financial market regulator, had put forth a timetable for switching to International Financial Reporting Standards (IFRS), produced by the International Accounting Standards Board-a private-sector regulator based in London. SEC-regulated U.S. corporations were to be required to use IFRS, possibly as soon as $2014 .^{1}$ Only a decade earlier, the suggestion that the United States might adopt IFRS "would have been laughable," 2 as many experts expected U.S. standards to become the de facto global standards.

The SEC's decision to defer to an international private standardsetter is part of a broader and highly significant shift toward global private governance of product and financial markets. What is at stake? Financial reporting standards specify how to calculate assets, liabilities, profits, and losses-and which particular types of transactions and events to disclose-in a firm's financial statements to create accurate and easily comparable measures of its financial position. The importance of these standards, however, runs much deeper. Through the incentives they create, financial reporting standards shape research and development, executive compensation, and corporate governance; they affect all sectors of the economy and are central to the stability of a country's financial system.

\footnotetext{
${ }^{1}$ See, for example, Hughes, "US Set to Adopt IFRS Rule" (2008). The SEC's proposed "Roadmap to IFRS Adoption" of August 2008 has been elaborated and extended by the February 2010 "Work Plan." The plan envisages that, after review and confirmation in 2011, it would become mandatory for all U.S. companies whose shares are traded on a U.S. stock exchange to prepare their regular financial statements on the basis of IFRS. This requirement is to be phased in over several years (see chapter 4 for details).

${ }^{2}$ House, "Global Standards Here to Stay" (2005), 72.
} 
IFRS, however, differ in some important respects from U.S. Generally Accepted Accounting Principles (GAAP), the financial reporting standards so far required by the SEC. ${ }^{3}$ Having evolved in a very litigious business environment, U.S. GAAP are highly detailed and address a vast range of specific situations, protecting companies and auditors against lawsuits. IFRS, by contrast, have traditionally been principles-based. They lay out key objectives of sound reporting and offer general guidance instead of detailed rules.

The implications of a switch from U.S. GAAP to IFRS are therefore momentous: twenty-five thousand pages of complex U.S. accounting rules will become obsolete, replaced by some twenty-five hundred pages of IFRS. Accounting textbooks and business school curricula will have to be rewritten, and tens of thousands of accountants retrained. Companies will need to spend millions of dollars to overhaul their financial information systems; many will need to redesign lending agreements, executive compensation, profit sharing, and employee incentive programs. ${ }^{4}$ And investors as well as financial analysts will need to learn how to interpret the new figures on assets, liabilities, cash flow, and earnings. The implications run deeper still. As explained by Robert Herz, chairman of the organization producing U.S. GAAP-the Financial Accounting Standards Board (FASB): "Liv[ing] in a world of principles-based standards involves [far-reaching] changes-institutional changes, cultural changes, legal and regulatory changes." ${ }^{5}$ In sum, the proposed shift of rule-making authority from the domestic to the international level will affect numerous and diverse actors, and bring deep changes to the American financial market.

The United States is not the only country to switch to international standards, of course. As figure 1.1 shows, the number of jurisdictions where stock market regulators permit or even require the use of IFRS has exploded since 2001—despite the substantial costs of the switch for many countries' firms, investors, and regulators. ${ }^{6}$ In the member states of the

\footnotetext{
${ }^{3}$ See, for example, Cunningham, "The SEC's Global Accounting Vision: A Realistic Appraisal" (2008); Deloitte, "IFRS and US GAAP" (2008); Nobes and Parker, eds., Comparative International Accounting (2008), 74ff, 184f; Smith, "Convergence Is 'Some Way Off'” (2007). Cf. Harris, International Accounting Standards versus US-GAAP Reporting (1995).

${ }^{4}$ Rezaee et al. warn that these costs may exceed the costs of compliance with the SarbanesOxley legislation, "Convergence in Accounting Standards" (2010), 145.

${ }^{5}$ Robert Herz, as quoted in Dzinkowski, “Convergence or Conversion?” (2008), 115.

${ }^{6}$ Until 2001, international financial reporting standards were known as International Accounting Standards (IAS). Jurisdictions with domestic stock markets, only. Financial reporting
} 
THE RISE OF PRIVATE REGULATION

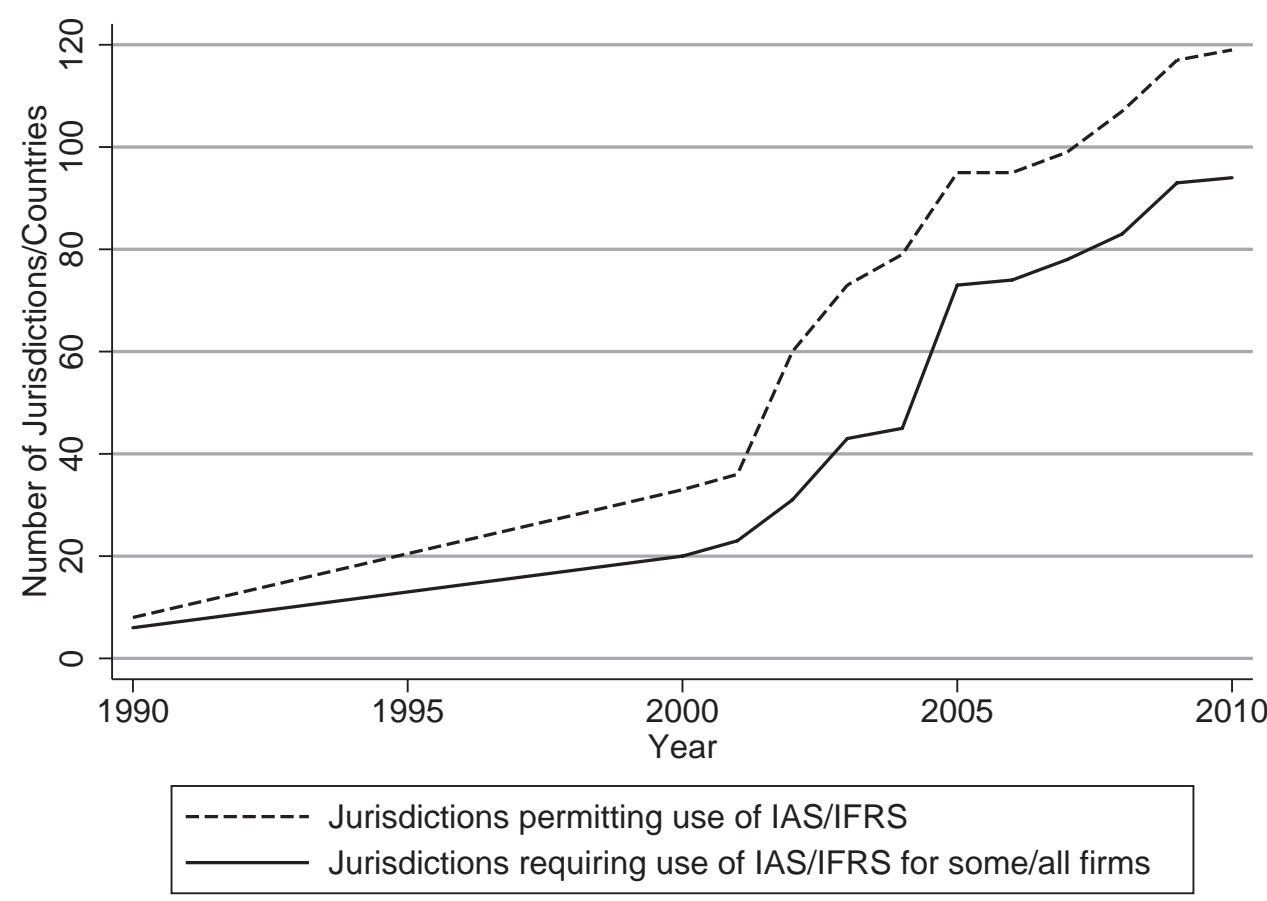

Figure 1.1 Use of IAS/IFRS as Allowed or Required by Stock Market Regulators

Number of jurisdictions permitting use includes number requiring use. Sources: IASC, Survey of the Use and Application of International Accounting Standards (1988); Cairns, International Accounting Standards Survey 2000 (2001); Nobes, GAAP 2000: A Survey of National Accounting Rules (2001); Deloitte Touche Tohmatsu, "Use of IAS for Reporting by Domestic Companies, by Country" (2002), "Use of IFRS for Reporting by Domestic Listed Companies, by Country” (2004), IAS in Your Pocket (2001, 2002), and IFRS in Your Pocket (2003, 2005-10).

rules are reported by "jurisdiction" because a few states contain more than one jurisdiction (e.g., Abu Dhabi and Dubai in the United Arab Emirates) and a few jurisdictions, such as Taiwan, are not universally recognized as states. Deloitte considers a jurisdiction to be permitting/requiring international standards when they either accept IFRS-based accounts without reconciliation or when the standards "adopted" as national standards are virtually all "word-for-word" equivalent to the international standards. Most of the countries requiring IAS/IFRS prior to 2000 were "developing or newly industrialised countries [that] do not have the resources to develop their own requirements" (Cairns, "Aid for the Developing World" (1990), 82). 
European Union (EU) and about sixty other countries across all continents, the use of IFRS is already mandatory for companies with publicly traded financial securities (stocks and bonds). ${ }^{7}$ And the trend is continuing: government regulators of several additional countries, including Japan, Canada, Brazil and India, have committed themselves to requiring IFRS in the near future. ${ }^{8}$

The global convergence of accounting standards is driven, in large part, by the international integration of financial markets and the increasingly multinational structure of corporations. These developments have not only led to economic growth and greater profits for many, but have also raised the costs of continued cross-national divergence of financial reporting standards for companies and investors. Indeed, crossnational differences in these rules are said to have exacerbated the global financial crisis of 2008-9-and the Asian Financial Crisis of 1997-98 before it. The belief that harmonization would bring substantial benefits has prompted firms and governments to push for a single common set of international financial reporting standards. Harmonization promises to increase the cross-national comparability of corporate information, improve the transparency of financial statements for shareholders, investors, and creditors, as well as achieve greater efficiency and stability in global capital markets.

Switching to IFRS, however, also brings costs, and these costs vary across countries. For countries with marginal capital markets and no proper accounting tradition, the costs are relatively minor. ${ }^{9}$ However, they can be considerable for countries or regions with large and sophisticated capital markets as well as long-standing domestic accounting traditions, such as the United States and many European countries. These costs will be larger the greater the difference between IFRS and long-established domestic rules and practices. Americans and Europeans therefore have particularly strong incentives to seek to influence the process of global rule-making in accounting. International standards that end up being identical or very similar to a country's domestic standards will minimize that country's costs of switching to "international" rules. And in highly

\footnotetext{
${ }^{7}$ Deloitte, "Use of IFRS by Jurisdiction" (2010).

${ }^{8}$ See Deloitte, “Accounting Standards Updates by Jurisdiction” (2010).

${ }^{9}$ The adoption of IFRS by developing countries is discussed for instance in Zeghal and Mhedhbi, "The Analysis of Factors Affecting the Adoption of International Accounting Standards by Developing Countries" (2006).
} 
competitive international markets, differential switching costs may jeopardize even the survival of disadvantaged firms. In sum, the international harmonization of financial standards promises substantial benefits but also will bring significant costs for some and hence distributional conflicts. ${ }^{10}$ Given the enormous stakes involved, the battle over global rules is likely to be intensely fought, especially between the United States and Europe.

The shift of financial rule-making to the IASB is part of a striking and much wider-yet little understood - trend that is the focus of this book: the delegation of regulatory authority from governments to a single international private-sector body that, for its area of expertise, is viewed by both public and private actors as the obvious forum for global regulation. In that particular issue area, such a private body is what we call the focal institution for global rule-making. This simultaneous privatization and internationalization of governance is driven, in part, by governments' lack of requisite technical expertise, financial resources, or flexibility to deal expeditiously with ever more complex and urgent regulatory tasks. Firms and other private actors also often push for private governance, which they see as leading to more cost-effective rules more efficiently than government regulation. ${ }^{11}$

Besides the IASB, two such private regulators stand out: the International Organization for Standardization (ISO) and the International Electrotechnical Commission (IEC). These organizations, in which states and governments as such cannot be members, are best described as centrally coordinated global networks comprising hundreds of technical committees from all over the world and involving tens to thousands of experts representing industries and other groups in developing and regularly maintaining technical standards. ISO and IEC jointly account for about 85 percent of all international product standards.

Product standards are technical specifications of design and performance characteristics of manufactured goods. ${ }^{12}$ Cross-national differences

\footnotetext{
${ }^{10}$ International standardization thus has characteristics of what game theorists call a coordination game with distributional conflict. See chapter 3, n1.

${ }^{11}$ See, e.g., Abbott and Snidal, "The Governance Triangle" (2009); Eichengreen, Toward a New International Financial Architecture (1999), esp. 35; Haufler, The Public Role of the Private Sector (2001); Vogel, "Private Global Business Regulation" (2008).

${ }^{12}$ More specifically, product standards cover properties such as interoperability, interconnectability, levels of safety, conformity, materials, systems of classification, methods of testing, the operation of systems, and quality assurance.
} 
in these standards matter little when product markets are predominantly domestic. The global integration of product markets, however, has greatly and lastingly increased international interdependence and thus created strong incentives to coordinate on common technical solutions. International standards offer such a solution. ISO and IEC product standards, in particular, play a critical role in facilitating international trade and boosting economic growth. Their numbers have been growing steadily over the last twenty-five years while the production of national standards has dwindled-as illustrated by the declining number of new German (DIN) standards shown in figure 1.2.

Little known until the mid-1980s, ISO and IEC have become prominent, in part because of the Agreement on Technical Barriers to Trade, negotiated during the Uruguay Round trade negotiations from 1987 to 1994. This agreement obliges all member states of the World Trade Organization (WTO) to use international standards as the technical basis of domestic laws and regulations unless international standards are "ineffective or inappropriate" for achieving the specified public policy objectives. ${ }^{13}$ Regulations that use international standards are rebuttably presumed to be consistent with the country's WTO obligations, whereas the use of a standard that differs from the pertinent international standard may be challenged through the WTO dispute settlement mechanism as an unnecessary nontariff barrier to trade and thus a violation of international trade law.

The commitment by governments to use international rather than domestic standards has enormous economic significance. Governments adopt hundreds of new or revised regulatory measures each year, in which product standards are embedded or referenced. ${ }^{14}$ And government regulations are just the tip of the iceberg, since consumer demand and concerns about legal liability create strong incentives for firms to comply with a wealth of product standards that are not legally mandated but define best practice.

The shift from domestic regulation to global private rule-making brings substantial gains, particularly to multinational and internationally competitive firms, for which it opens up commercial opportunities previ-

\footnotetext{
${ }^{13}$ TBT-Agreement, Article 2.4.

${ }^{14} \mathrm{~A}$ small, though increasing, share of these new or revised national regulations is due to international regulatory harmonization, see Kawamoto et al., "Product Standards, Conformity Assessment and Regulatory Reform” (1997), 281; WTO, Fourteenth Annual Review of the Implementation and Operation of the TBT-Agreement (2009), 3-4.
} 


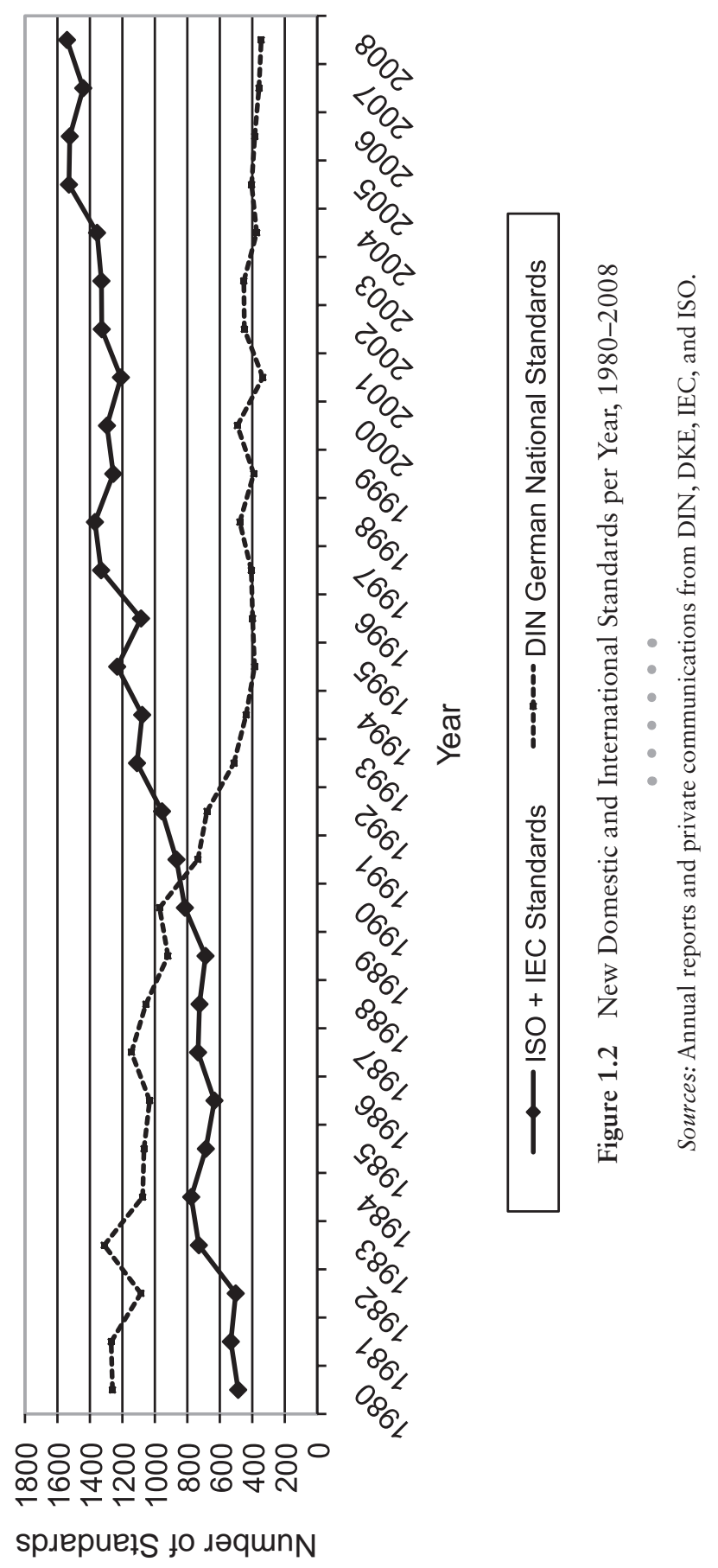


ously foreclosed by cross-national differences in standards and related measures. The share of U.S. exports affected by foreign product standards, for instance, had risen from 10 percent in 1970 to 65 percent in 1993 , and by the time the WTO's TBT-Agreement came into force, crossnational differences in product standards were estimated to result in a loss of $\$ 20-\$ 40$ billion per year in U.S. exports alone. ${ }^{15}$ United States imports and consumers were also affected. For some manufacturing industries, U.S. nontariff barriers in the late 1980s created losses due to increased costs and reduced trade equivalent to a tariff of 49 percent. ${ }^{16}$ Even today, about one third of global trade in goods-valued at $\$ 15.8$ trillion for 2008-is affected by standards that often differ across countries, and the boost in trade from a complete international harmonization of product standards would be equivalent to a reduction in tariffs by several percentage points. ${ }^{17} \mathrm{~A}$ shift to common international standards thus benefits internationally competitive firms by increasing their export opportunities. It also benefits consumers who, as a result of increased trade and competition, have access to a broader range of goods and services and can buy them more cheaply.

At the same time, the shift to global private-sector regulation also entails costs. To comply with international product standards, for example, firms may have to redesign their products, retool their production methods, or pay licensing fees to other firms whose proprietary technology may be needed to implement the international standard efficiently. These costs can be massive, to the point where some feel forced to discontinue production of certain goods or even go out of business. ${ }^{18}$

\footnotetext{
${ }^{15}$ Kawamoto et al., "Product Standards, Conformity Assessment and Regulatory Reform" (1997), 280; Mallett, "Why Standards Matter" (1998-99); NRC, Standards, Conformity Assessment, and Trade (1995).

${ }^{16}$ Melo and Tarr as quoted in OECD, An Assessment of the Costs for International Trade in Meeting Regulatory Requirements (2000), 9.

${ }^{17}$ Kawamoto et al., "Product Standards, Conformity Assessment and Regulatory Reform" (1997), 283; Moenius, "Information versus Product Adaptation: The Role of Standards in Trade" (2004); WTO, World Trade Report (2009), 4-5. It remains difficult to calculate the trade effects of standards precisely, due to data limitations, as noted by the WTO, World Trade Report (2005), 58ff.

${ }^{18}$ International product standardization thus also often resembles a coordination game with distributional conflict. The overall gains, as well as the conflicts over the distribution of costs in international standard-setting have been recognized and illustrated in recent economic analyses by the WTO, the World Bank, UNCTAD, the OECD and others. We discuss them in more detail in chapter 6 .
} 
In sum, while the convergence on a single set of international standards may bring overall gains for all countries, those gains may differ greatly across countries and especially across firms. Firms therefore have a strong incentive to seek to influence the process of international rule-making to minimize their switching costs. For those who succeed in pushing their domestic standards for adoption as international standards, switching costs will be minimal. The stakes thus are high in global private regulation, and severe conflicts of interest are likely, as noted in a remarkably frank statement by Gerald Ritterbusch, director of standards and regulations at the U.S. firm Caterpillar, during a Congressional hearing:

How do standards impact our ability to compete internationally? ... When we have domestic standards that are different from international standards, everybody loses. We lose domestically because we must build a product that is different from products we sell internationally. That raises ... [our production] costs, hurt[ing] American consumers ... [and] caus[ing for us] unfavourable opportunities in foreign markets. What is needed is that [our] domestic standards experts aggressively participate in international standards developments to get domestic standards accepted ... The first to [propose a standard for adoption at the international level] ... will most likely succeed. Thus it is necessary ... [to] get to the international arena ahead of standards experts from other countries. ${ }^{19}$

A distinctive feature of global regulators such as ISO, IEC, and IASB is not only that they are private but also that they are what we call focal regulatory institutions-uncontested in their respective areas. Their prominent position in the regulation of global markets raises pressing empirical and analytical questions:

- Who exactly writes the rules in these private organizations?

- Who wins and who loses-and why-when standard-setting takes place in these private international organizations? What,

\footnotetext{
${ }^{19}$ U.S. House of Representatives, Committee on Science (Hearing) Standards-Setting and United States Competitiveness (2001), 24, 94. Ritterbusch served for 30 years on various technical committees of the Society of Automotive Engineers and also held the chairmanship of the ISO technical committee on earthmoving machinery.
} 
in other words, is the nature of politics in private-sector rulemaking?

- What defines power in these organizations, and how does it operate?

- Do all of those who have a commercial, financial, or sociopolitical stake in the content of these rules have a voice in the process?

Specific, empirical answers to these questions are hard to come by, in large part because these global regulators are private. Financed mostly by voluntary contributions from private-sector stakeholders, they are not subject to public oversight, and the writing of specific rules is in the hands of groups of experts who are not required to keep records of their proceedings. It is therefore difficult to obtain systematic information about these regulatory processes. Yet, global private regulation has in recent years become vastly more important and is now a phenomenon of considerable social and economic consequence-it matters to understand it. This makes the lack of reliable information all the more problematic, since comprehensive data are a crucial prerequisite for both assessing and improving the performance and processes of global private regulators.

In this book, we provide not only a framework for the analysis of private regulation but also detailed empirical answers to the above questions. We are able to test competing theoretical propositions about global regulation thanks to eight years of collecting extensive information on private rule-making in central areas of the global economy. As part of this research, we have conducted two comprehensive multi-country, multiindustry business surveys-one about international financial reporting standards and IASB standardization, the other about international product standards and ISO/IEC standardization. The surveys covered a broad range of issues, including firms' use of standards, familiarity and satisfaction with various standards, cost of switching to international standards, methods of seeking influence in private rule-making, assessments of such methods, reasons for getting involved or staying out, and general trends. We supplement the analysis of the survey data with insights gained from a large number of interviews with senior and mid-level managers, current and former IASB and ISO/IEC staff, and government regulators. Together, these data allow us to provide the first systematic analysis of key private institutions for the regulation of global markets. 


\section{The ARgument IN BRIEF}

International standardization is sometimes described as an apolitical, scientific process of developing or identifying the technically optimal solution to a regulatory or technical challenge. In this view, consensus and thus rule-making is easy because "scientific technological knowledge is everywhere the same." 20 Much of the language used by private-sector regulators to describe their operations reinforces this view of standardization. The ISO, for example, characterizes its standards as "based on international consensus among the experts in the field ... [and reflecting] the state of the art" of science and technology. ${ }^{21}$ Similarly, the IASB notes that nationality and other political considerations play no part in the appointment and decisions of its expert rule-makers. They are chosen because they have "the best available combination of technical skills and background experience of relevant international business and market conditions in order to contribute to the development of high quality global accounting standards." 22

We argue that such views are naïve. Standards do not embody some objective truth or undisputed scientific wisdom professed by experts. And global regulatory processes are not apolitical, for two reasons. First, expertise is not a single correct set of beliefs about what works or does not. A German accountant, or Wirtschaftsprüfer, who underwent eight years of studies, training, and examinations, is every bit as expert as an American Certified Public Accountant (CPA). Nevertheless, these experts are likely to disagree vigorously on how best to approach a wide range of financial reporting challenges, because any accounting tradition or school is deeply rooted in the business and legal cultures of a given country. As an official of the Accounting Standards Board of Japan (ASBJ) puts it: "There is no right or wrong answer. . . . It's like religion-Christianity or Buddhism." 23 Global standardization is rarely about reaching a compromise among different regulatory models and approaches (a fusion between Christianity and Buddhism would be impossible to engineer) but instead about battles for preeminence of one approach or solution over

\footnotetext{
${ }^{20}$ Loya and Boli, "Standardization in the World Polity" (1999), 188.

${ }^{21}$ ISO, "Discover ISO: The ISO Brand" (2009).

${ }^{22}$ IASCF, Revised Constitution (2009), 12.

${ }^{23}$ Quoted in Jopson and Pilling, "Accounting Rivals Face a Struggle to Stay in Tune" (2005).
} 
another. The language accompanying these processes is technical; the essence of global rule-making, however, is political. Such rule-making typically has important distributional implications, generating winners and losers. To lose may mean higher production costs, steeper costs of switching to international standards, lower international competitiveness, loss of export markets, and even risk of corporate demise. As discussed in greater detail in chapters 4 and 6 , and nicely put by James Barcia, U.S. congressman and member of the Subcommittee on Environment, Technology and Standards: "New [international] standards can be the source of enormous wealth or the death of corporate empires. With so much at stake, standards arouse violent passions." ${ }^{24}$ In short, global private regulation should be understood and analyzed as an intensely political process, even if the politics may be hidden beneath a veneer of technical rhetoric.

Second, IASB, IEC, and ISO are not operationally self-sufficient, and their officials do not work in isolation. They heavily rely on private-sector standards bodies at the national level for logistical and technical support (as discussed in detail in chapters 4 and 6). ${ }^{25}$ The domestic bodies thus are part and parcel of the global institutional structure of standardization; in a sense, they form the institutional backbone of the global regulators. Domestic standards bodies, however, are not disinterested aides to the international bodies. They seek to promote and defend at the international level the regulatory preferences of their domestic stakeholders to minimize domestic switching costs. At the same time, domestic standards bodies and systems vary widely in resources and organizational structures and are, therefore, likely to exert differing degrees of influence on global regulatory processes.

These two points-the political nature of standardization and the importance of domestic standards bodies in global processes-lay the basis for our argument, which can be summarized as follows: technical expertise and financial resources are necessary but not sufficient conditions for successful involvement in global private-sector standardization. It is timely information and effective representation of domestic interest that

\footnotetext{
${ }^{24}$ U.S. House of Representatives, Committee on Science (Hearing), Standards-Setting and United States Competitiveness (2001), 19.

${ }^{25}$ The modalities of support vary between IASB and ISO/IEC as discussed in chapters 4 and 6 , but the centrality of domestic standards bodies in global private regulation is a constant theme.
} 
confer the critical advantage in these regulatory processes, determining who wins or loses. Such representation occurs not through states, as in traditional intergovernmental organizations, but through domestic privatesector standard-setters. Their ability to speak with a single voice and effectively promote domestic preferences, however, varies-mostly for historical reasons.

The foundations of most domestic institutional structures of standardization were laid many decades ago and have changed little over time. Some countries have a single domestic institution for standard-setting or a clear organizational hierarchy, while in other countries, rule-making authority is fragmented among multiple competing standard-setters. Contestation is common in the latter system but largely absent in the former. Both systems have served their respective domestic economies well by generally producing (in very different ways) high-quality standards over time. However, they differ in how well they serve the interests of domestic stakeholders now that the main focus and locus of standardization has shifted to the global level.

Who then wins or loses and why? We argue that firms operating in a hierarchical and coordinated domestic system are likely to win because their system fits more naturally with the global structure, where a single regulator is the clear focal point. Such a domestic system enables a country's stakeholders to speak with a single voice and in a timely fashion on the global stage. We call this a case of high "institutional complementarity" between the domestic and global levels. High institutional complementarity implies that the interaction between domestic and global institutions is smooth and easy, yielding decisive strategic benefits to the firm in terms of effective interest representation in global rule-making and timely information. By contrast, firms in a fragmented domestic system, characterized by contestation among rival standardsetters, are at a distinct disadvantage. Their system renders both effective national interest representation and domestic diffusion of information about new global standards projects more difficult and thus fits relatively poorly with an institutional structure at the global level consisting of a single focal regulatory body for a given issue area. This we call a case of low institutional complementarity between the domestic and global levels. Generally, we argue that influence in global private governance is significantly a function of how complementary a country's domestic institutions are with the prevailing institutional structure at the international level. 


\section{Organization OF THE BOOK}

Part I presents the analytical framework. To situate our analysis in the larger literature on globalization and regulation, we develop in chapter 2 a typology of global regulation, which differentiates the institutional setting for rule-making, which is either public or private, from the global selection process, which is either market-based or nonmarket-based. We therefore distinguish four types of global regulatory governance: the first type, which we label "public (governmental) nonmarket standard-setting," involves collaboration through traditional intergovernmental organizations (IGOs) or transgovernmental cooperation among domestic regulators. It has a long tradition and has been the focus of most of the political science literature on global regulation. Another type is market-based private regulation. It entails rule-making by firms or other bodies competing, individually or in groups, to establish their preferred technologies or practices as the de facto standard through market dominance or other strategies. This type of global regulation has also attracted substantial analytical attention, especially from economists. A third type of global regulation-private yet nonmarket-based-is the focus of our book. Largely overlooked in the literature, regulation by focal private bodies, such as IASB or ISO/IEC, is the predominant type for major parts of the international political economy today. Finally, a fourth type of regulation results from marketlike international competition between public regulatory agencies. The discussion of our typology is followed in chapter 3 by the presentation of our theoretical argument, summarized above.

Part II deals with private regulation in global financial markets. In chapter 4, we first provide a brief account of how the IASB became the focal institution for setting financial reporting standards at the international level, then analyze the institutional structures of IASB and corresponding institutions at the domestic level in the United States and the three largest European countries: Germany, France, and the United Kingdom (as well as pertinent EU-level regional institutions). The United States has a single private organization that is uncontested as the institutional setting for developing financial reporting standards at the domestic level, and consequently provides an efficient and effective mechanism for aggregating preferences. Accounting standard-setting in Europe, by contrast, is characterized by institutional fragmentation and competition for authority among multiple institutional centers, both at the domestic and the European levels. Our general analytical approach suggests that the 
resulting differences in institutional complementarity put U.S. firms in an advantageous position vis-à-vis European firms when standard-setting shifts to the international level.

Chapter 5 presents the main empirical analysis of global financial reporting standard-setting. Our international business survey, conducted among hundreds of CFOs and other senior financial managers of companies listed on the main stock exchanges in France, Germany, the United Kingdom, and the United States allows us to test the hypotheses derived from our analytical framework, along with alternative explanations. As predicted by the framework, we find that U.S. firms are substantially more successful than European firms when they try to influence international financial reporting standards. Responses to a battery of questions about different methods of influencing IASB standard-setting show that the greater success of American firms is indeed due to the greater fit or complementarity between IASB and U.S. domestic institutions. The statistical analyses of survey findings are supplemented by information gathered through open-ended survey questions and interviews with corporate finance experts, accounting experts in government and academia, as well as private regulators at the domestic and international level. Qualitative information from these questions and interviews provides additional support for our argument.

Part III examines private regulation in global product markets. Chapter 6 begins by providing a brief account of how ISO and IEC became, for most industries, the focal institutions for setting international product standards. We then briefly review the global institutional structure and decision-making procedures before describing the domestic structures in the United States and Europe. Rule-making for product markets constitutes a particularly interesting counterpart to private rule-making for financial markets, because the differences in product standard-setting institutions at the domestic and regional levels are the exact opposite of what we observe in accounting standard-setting. The institutional structure for setting product standards in the United States is characterized by institutional fragmentation and contestation among competing standard-setters. In Europe, by contrast, the domestic standard-setting institutions are characterized by a high degree of coordination and organizational hierarchy. We then analyze the differential complementarities between the domestic and the international institutions for the United States and the Europeans, respectively, and explain why it is more likely for Europeans than Americans to shape the content of product standards in ISO and IEC. 
In chapter 7, we turn to various tests of the hypotheses developed in chapter 6 and present the findings from the international business survey that we conducted in the United States and Europe among more than a thousand senior and mid-level managers with responsibility for technical standards in research and development, production, or marketing in five main economic sectors. We find compelling evidence that high complementarity between standard-setting institutions at the domestic level and the institutional structure of standardization at the international level favors European over American interests in ISO and IEC. By contrast, the relatively poor fit between U.S. domestic institutions and the international structure puts American firms at a disadvantage.

In chapter 8 , we extend our discussion of the concept of institutional complementarity and examine the implications of complementarity for our theoretical understanding of the relationship between power and institutions. We also highlight contributions of our research to several current debates among scholars of political science, sociology, law, economics, and business administration about issues such as the changing nature of regulatory politics and nontariff barriers to trade. In the conclusion, we examine the implications of our research for our understanding of global governance and for current policy debates, which often still underappreciate the political nature of seemingly technical activities such as standard-setting, and the implications for corporate strategy.

Private regulation and the interaction between domestic and international institutions are important elements of global governance. They warrant greater analytical attention from economists, political scientists, legal, and business scholars. Global private regulation is also a very timely issue for practitioners, as evidenced by now frequent reports about controversies over IFRS and ISO standards in the financial and business press. And these standards are substantively increasingly important for practitioners: product standards often are crucial for commercial success in global markets. Accounting standards affect share prices as well as risk assessments and hence the cost of insurance. Finally, global private rule-making is an important complement to, or even substitute for, formal legal collaboration through international treaties among governments. In short, global private governance is tremendously important for practitioners in many fields. Much of the process of private rule-making, however, remains shrouded in secrecy. This book aims to end the secrecy, opening the black box of private rule-making to scrutiny for a broad and varied audience. To do so, we have avoided jargon and technical minutiae-sometimes by moving more detailed discussions into appendices. 


\section{BOX 1.1}

\section{The Modern Meaning of Regulation and Standards A Definitional Clarification}

The term regulation is commonly used to describe technical rules issued by government departments and agencies. Such regulations provide clarity and guidance in their respective areas of responsibility. In the United States, for example, the Food and Drug Administration (FDA) has a legislative mandate to keep unsafe food off the market; FDA regulations define that task with respect to specific products. Although regulations are distinct from statutory law because they are not the work of the legislature, their legal effect is direct and binding.

The role played by regulations in the U.S. context is similar to the role of standards under the EU's so-called "New Approach" to regulatory harmonization, introduced in the mid-1980s, which involves the delegation of regulatory functions to private-sector standardization bodies. Under the "New Approach," EU legislation is limited to laying down in directives mandatory so-called essential requirements for health, safety, environmental, and consumer protection. These directives cover entire sectors rather than single products. The elaboration of the technical specifications that satisfy the essential requirements is delegated to two major European standardization bodies. The national authorities are obliged to recognize that products manufactured according to the standards of these private organizations are presumed to conform to the essential requirements specified in directives (EU law); they must thus allow these products to circulate freely in the EU market.

In theory, European standards are voluntary. That is, producers who come up with alternative technical solutions that meet the level of product safety or safeguards for consumer health, specified in the directives, cannot be excluded from the market. However, these producers carry the burden of proving that their standards do indeed safeguard health and safety at the required levels. In practice, then, the effect of standards is direct and binding since the cost and difficulty of proving equivalence are enormous. Similarly, many of the standards discussed in this book, including ISO, IEC, and IASB standards, are binding if not by law then by practical necessity or market pressure. We thus use the terms global regulation, rules, and standards interchangeably in this book and define them as rules established by expert bodies prescribing de jure or de facto the quality or performance of a given practice, procedure, or product. 